\title{
Irpe From the Gold Standard to the Floating Dollar Standard: An Appraisal in the Light of Marx's Theory of Money
}

\author{
RAMAA VASUDEVAN \\ Department of Economics, Colorado State University, Fort Collins, CO 80523-1771; \\ e-mail: Ramaa.vasudevan@colostate.edu
}

Received December 20, 2007; accepted October 22, 2008

\begin{abstract}
The paper explores the insights offered by Marx's analysis of the emergence of "world money" into the workings of the international gold standard period and the post-Bretton Woods floating dollar standard. In a curious inversion of the traditional formulations drawing on Lenin, imperial hegemony in today's context would seem to be associated with net capital imports (rather than exports) by the dominant country. In particular, I argue that in a context where the role of "world money" rests on the monetary liabilities of a dominant state, in the form of credit money - "fictitious capital" - rather than bullion, there is an easing of the external constraint on the advanced countries in the core with the impact of the debt-deflationary spiral and financial fragility being borne disproportionately by the periphery. The theorization of world money needs to address the relation between the state and the financial system: the asymmetric manner in which countries outside the core were incorporated into the monetary system, and the role that financialization plays in preserving the hegemony of the dominant currency.
\end{abstract}

JEL classification: F33, F34, F59

Keywords: marx's theory of money; gold standard; dollar standard

In a curious inversion of the traditional formulations drawing on Lenin, imperial hegemony today is associated with net capital imports (rather than exports) by the dominant country. The United States, the dominant imperialist nation, has sustained a rising external debt burden for more than two decades. The unprecedented situation of an imperialist debtor country, and its relative immunity from destabilizing speculative attacks through two cycles of appreciation and depreciation, has been ascribed to the privileged position of the dollar internationally, "the exorbitant privilege" that the United States is able to exercise (Gourinchas and Rey 2005).

Author's Note: The development of the argument of this paper owes a lot to discussions with Duncan Foley. I would also like to acknowledge the critical and insightful comments of Suzanne De Brunhoff on an earlier version of this paper.

Review of Radical Political Economics, Volume 41, No. 4, Fall 2009, 473-491

DOI: 10.1177/0486613409341369

(C) 2009 Union for Radical Political Economics 
De Brunhoff (2005), while discussing the contradictory process of the integration of the world capitalist system under a dollar standard, suggests that the complex relation between capitalism and imperialism should be subject to further scrutiny. This paper is an attempt to further explore this relation using the conception of "world money" in Marx's analysis as the point of departure. This project is of course confounded by the fragmentary nature of Marx's writing on the subject, and the fact that he was unable to bring his analyses together in a finished form during his lifetime. But Marx's conception offers crucial insights that help to make sense of some of the developments and contradictions of the international monetary arrangements of both the floating dollar standard and the earlier international gold standard. The paper suggests that an aspect of imperial power is mediated through the asymmetric integration of countries in the periphery into the global financial system in which the role of world money is played by the currency of the dominant advanced capitalist country.

The historical context of the mid-nineteenth century in which Marx developed his critique of political economy is quite different from today's world, but the analytical framework remains relevant to the study of modern international monetary systems and the manner in which the fundamental contradictions of the form of money are reproduced and generalized with the transition from commodity money to credit money. The phenomenon of financialization is integral to the analysis of this transition.

The basic principle of financialization is the transformation of future streams of (profit, dividend, or interest) income into a tradable asset like a stock or a bond. Financialization can be understood as a "pattern of accumulation in which profit making occurs increasingly through financial channels rather than through trade and commodity production" (Krippner 2002). It reflects the systemic power and importance of "financial markets, financial motives, financial institutions, and financial elites in the operation of the economy and its governing institutions, both at the national and international level" (Epstein 2001).

In part 1 of the paper, Marx's analyses of the emergence of world money and the process of financialization is situated in the context of his particular approach to the analyses of the money-form. ${ }^{1}$ Part 2 then attempts to comprehend the evolution of the international gold standard and the emergence of the floating dollar standard after the collapse of the Bretton Woods system from within the framework of Marx's discussion of the moneyform. Such a theorization of world money, I argue, needs to address the relation between the state and the financial system, the asymmetric manner in which countries outside the core were incorporated into the monetary system, and the role that financialization plays in preserving the hegemony of the dominant currency.

\section{Marx’s Analytical Approach}

\section{I.I Marx's Theory of Money}

For Marx the necessity of world money emerges from the logic of simple commodity production and contains the fullest expression of the potentialities and contradictions of the money-form.

1. The analysis draws on Marx (1972[1859], 1973, 1976[1867], 1981[1895]). These represent the important milestones in the development of Marx's theory of money. 
In world trade, commodities develop their value universally. Their independent value form, thus confronts them, here too, as world money. It is in the world market that money first functions to its fullest extent as the commodity whose natural form is also directly, the social form of realization of human labor in the abstract. (Marx 1973: 240)

Marx develops his conception of world money through the analyses of the simplest relations of exchange of the commodity (Marx 1972[1859], 1976[1867]). This is the essence of Marx's method, his point of departure from classical political economy. ${ }^{2}$ Exchange produces the doubling of the commodity as use value and exchange value. The exchange value of the commodity then acquires a separate, material existence, along side and in opposition to all other commodities as money; it is the universal equivalent.

Marx explored the development of the different forms and functions of money and the contradictions of the money-form and demonstrated that even in its simplest form as "gold money," money is produced like any other commodity, but its laws of circulation are quite distinct. The argument is not simply that of theoretical necessity but also derived from actual historical evolution (De Brunhoff 1976; Foley 1983). He went beyond the mere fact of the existence of "commodity money" and sought to discover "how and why and by what means a commodity becomes money" (De Brunhoff 1976).

Marx's elaboration of a theory of money encompasses its roles as a measure of value, a medium of circulation, and finally as a means of payment or "money proper." The logical order in which these different aspects of the money-form are developed is also the key to understanding the contradictions contained within it. As money develops through the process of hoarding into the "embodiment of abstract social wealth" it assumes a special function as a means of payment. This transforms the commercial relation between the seller and buyer into the financial relation between a creditor and debtor. The compulsion to sell is now no longer an individual necessity but a social necessity independent of the seller's individual wants. Money from being a means of circulation now develops into its goal or final result. ${ }^{3}$

The analyses of the role of money as a means of payment forms, on one hand, the basis for Marx's discussion of the emergence of credit money and the financial system, which correspond to a more developed stage of capitalism. On the other, within the logical structure of Marx's theory of money, money in its form as world money also stems from the analyses of money as a means of payment (De Brunhoff 1976).

\section{I.2 The Financial System and Financialization}

Turning first to credit and the financial system, the unity of the financial system, while being derived from the monetary basis of credit, is related to the division of the capitalist class into financial and industrial capitalists. The development of trade and the capitalist

2. Arnon (1984) and Rosdolsky (1977) point to the crucial evolution in Marx's analysis between writing the notes for Grundrisse and the Contribution to the Critique of Political Economy. It is in the latter work that Marx derives the function of money as money proper from simple commodity production, prior to analyzing the development of the capitalist credit system.

3. "The conversion of commodity into money as a final act, or the first metamorphoses of a commodity as an end in itself, which in the case of hoarding seemed to be a matter of caprice on the part of the commodity owner, becomes now an economic function. The motive and essence of sale for the sake of payment becomes from a mere form of the process of circulation its self emanating substance" (Marx 1973: 190). 
mode of production transforms the natural, spontaneous basis of the credit system in relations of commerce into a more complex financial system. Alongside this changing relation is the process of concentration and organization of money capital in the banking and financial system, the rise to dominance of "finance capital." Credit offers absolute command over capital and property of others (Marx 1981[1895]: 570).

As a means of payment, money has features of both a financial asset and of a general equivalent (De Brunhoff 1989). The monetary characteristics of credit money subject it to laws of monetary circulation. ${ }^{4}$ The financial role of money preserves its role as a general equivalent, distinct from other commodities. In some senses it is the fruition of the moneyform, and the opposition between the class of commodities, as a whole, and money. Marx (1973: 147-150) elaborates on how the money-form arose from the contradiction between the dual existence of commodities as use value and as exchange value. This split the act of exchange into two mutually independent acts of purchase and sale, and the contradiction of the commodity form is displaced in a manner that contains the possibility of crisis. The next level of contradiction arises when the overall movement of exchange itself becomes separate from the exchangers, so that there appears a doubling of exchange; on one hand "exchange for the sake of consumption" and on the other "exchange for the sake of exchange" in the mercantile estate (commerce). Finally, the unfolding of the internal contradictions of the money form manifests itself in the separation of financial operations from real transactions and actual trade (Rosdolsky 1977).

Just as exchange value, in the form of money, takes its place as the general commodity alongside all particular commodities, so does exchange value as money therefore at the same time take its place as a particular commodity alongside all other commodities. ... Money comes into contradiction with itself and with its characteristics by virtue of being itself a particular commodity and of being subject, therefore to particular conditions of exchange in its exchange with other commodities, conditions which contradict its general unconditional exchangeability. (Marx 1973: 150)

Money "becomes a commodity like other commodities and at the same time it is not a commodity like other commodities." Capitalist production "constantly strives to overcome the metallic barrier, which is both a material and imaginary barrier to wealth and its movement, while time and again breaking its head on it" through the credit system (Marx 1981: 708). From being a produced commodity, the money-form evolves with the development of interest bearing capital to that of a financial asset. A new source of contradiction is opened as "money business" separates from "commerce proper" (Marx 1973: 151). This contradiction which Marx derives from the analysis of the functions of money under capitalist exchange relations - in particular the function of money as a means of payment - provides an insight into the origins of the phenomena of financialization within Marx's unitary conception of money and credit. ${ }^{5}$

4. The correct order of explanation, in opposition to the monetarist explanations, remains from the needs of circulation to the mechanism that meets these needs (Foley 1983, 1986).

5. This exposition of how "finance" emerges logically from the contradictions of the money-form in Grundrisse (Marx 1973) provides a insightful approach to Marx's discussion of fictitious capital in Capital, Volume III (Marx 1981[1895]). 
In Marx's analytical framework, the starting point of interest formation is the confrontation of money and productive capital as entities that play quite different roles in the reproduction process. The quantitative distribution of gross profit between the money (financial) capitalist and the industrial capitalist gives rise to a qualitative distinction between interest and profit of enterprise. Competition leads to the establishment of a uniform rate of interest rate. Part of profit is now externalized as interest and interest emerges as something autonomous that would be yielded even without productive application. ${ }^{6}$ The grounds for division into interest and profit of enterprise are turned into the grounds for existence of profit, and the real social relations underlying interest payments appear in an inverted form. ${ }^{7}$

The externalization of the interest rate also leads to a principle of valuation that is distinct from and opposed to that based on production and labor values (De Brunhoff 1976). Instruments representing titles to future flows of income are valued by capitalization of these future flows at the rate of interest. Thus public debt represents the capitalization of anticipated tax revenues and the value of equity stock reflects the capitalization of future dividend streams. Banking assets that do not correspond to savings, deriving entirely on banking activity, again allow the financial system to grow by feeding on its own substance through the capitalization of future earning flows. This is the origin of fictitious capital which is essentially the phenomena of financialization (Marx 1981[1895]).

In the light of Marx's analytical framework, financialization emerges as a logical and historical necessity from the inherent contradictions of the capitalist exchange relation. The evolution of the credit and financial system accelerates the material development of productive forces and the creation of the world market, but at the same time accelerates the violent outbreak of contradiction and crisis. ${ }^{8}$

Minsky (1975) in his interpretation of Keynes addressed the implications of the evolution of the financial system and the speculative aspects of asset holding for investment, laying out an analysis in terms of a two-price model, one set being prices for current output and the other set the prices of assets. Minsky (1975) posed the problem of financial instability in terms of the divergent movements of the prices for current output and those of financial and capital assets. Speculative investors sought opportunities for profit and capital gains within a vibrant financial structure propelling an endogenous shift from robustness to fragility. Finance "acts as the sometimes dampening sometimes amplifying governor for investment."

Marx has a strikingly similar discussion of credit cycles and the inherent tendency to increasing financial fragility as credit and the growth of fictitious capital spur the entry of jobbers and speculators (Marx 1981: 619-625, 634-645). Marx's theory of money - his unitary conception of money, credit, and the financial system - also points to a two-price

6. While this might be true for individual capitalists, it is not true for social capital as a whole. Money capital cannot yield interest on the basis of the capitalist mode of production without functioning as productive capital, i.e. without creating surplus value.

7. "Capital appears as a mysterious and self creating source of interest; of its own increase...the result of the overall reproduction process appears as a property devolving on a thing in itself..." (Marx 1981: 516).

8. "On one hand it develops the motive of capitalist production, enrichment by exploitation of others' labor, into the purest and most colossal system of gambling and swindling and restricts even more the already small number of exploiters of social wealth; on the other hand however it constitutes the form of transition towards a new mode of production" (Marx 1981[1895]: 571-2). 
model as money emerges from its commodity roots to take the form of fictitious capital. Fictitious capital is subject to a valuation principle distinct from that governing other commodities. In Marx's analysis of the money-form within the simple commodity framework, we see the seed of the contradictions of the capitalist financial system in its more developed form with the growth of financialization.

\section{I.3 World Money in Marx’s Monetary Analysis}

Marx derived the conception of world money as the final stage of the analyses of the different metamorphoses that money undergoes in its different roles as a medium of exchange, a means of circulation, and a means of payment (money proper). Money emerges as "world money" after it "breaks through the barriers of home circulation to assume the part of a universal equivalent in the world of commodities." The role of money as world money, as an international means of payment and purchase, arises with the development of the world market and the extension of the international division of labor.

The crux of Marx's critique of the "currency school" and the quantity theorists arose from his analysis of the different roles of money (Lapavitsas 1996). This becomes apparent in a perusal of Marx's discussion of bullion crises (Marx 1981). Ricardo and Hume argued that the drain of gold during such crises was an outcome of excess supply of money that made money cheaper domestically. Money was understood solely as a means of circulation, and convertibility between coins and bullion would ensure an automatic adjustment mechanism that restored the balance internationally. In opposition to this formulation, Marx argued that the crises, which could be precipitated for instance by a bad harvest, take the form of a bullion drain precisely because what is in demand is gold (and silver) as money: an international means of payment. In times of crises the monetary nature of credit asserts itself in the drying up of credit. The drain of gold thwarts the convertibility of notes and forcible measures like raising the interest rate become necessary to guarantee the conditions of this convertibility. ${ }^{9}$

Money functions in the world market as a means of purchase only if the transaction is unilateral. As long as payments are equalized, money appears only in its "ideal form" as a unit of account. This monetary constraint asserts itself most strongly at times of crises, in particular when one country must suddenly settle its balances with another. It is the upheavals which require the appearance of money as money proper, the exclusive form of wealth (Marx 1972[1859]: 150, 1976[1867]: 243). The credit system is integral to the adjustment mechanism.

It is precisely the development of the credit and financial system that makes "the entire organism over-sensitive." It is also the mechanism by which balance of payments crises spread from one country to another. Thus,

9. The analyses of the bullion crises by Marx do not rest, however, on the convertibility to gold. He demonstrates that the crises would arise even if bank notes were used instead of bullion. If the other countries were willing to accept currency rather than money capital in the form of metal, then instead of being a draft on gold and silver, the bank would be forced to raise its discount rate depressing the price of bank drafts (Marx 1981: 121-2). Thus the bank's action in increasing the issue of notes merely devalues it, rather than increasing wealth. 
A crisis may break out first of all in England, the country that gives the most credit and takes the least because the balance of payments is due, which must be settled immediately, is against it even though the overall balance of payments is in its favor. . . The crash in England, introduced and accompanied by a drain of gold settles England's balance of payments, partly by bankrupting importers, partly by driving its commodity capital abroad at low prices, and partly by sale of foreign securities etc. The sequence now reaches another country. The balance of payments was temporarily in its favor; but now the normal interval between the balancing of payments and balancing of trade is abolished or at least cut short by the crisis; all payments have to be settled at once. The same situation repeats itself here. (Marx 1981[1895]: 623)

This discussion of contagion effects foreshadows Keynes's discussion of the inherent deflationary bias of the gold standard system. The problem for Keynes was that adjustment, while being voluntary for the creditor or surplus country, was compulsory for the deficit debtor country (Keynes 1980). It is noteworthy that Marx's discussion of the debt deflation spiral (as distinct from Keynes's discussion) places the effects within the developed commercial world.

In times of general crises the balance of payments is against every country, at least against every commercially developed country, but always against each of these in succession like volley firing - as soon as the sequence of payments reaches it ....in every case the same collapse follows. (Marx 1981: 624)

The implications for the economies outside this developed commercial center as they are integrated into the international monetary system thus bear investigation. While Marx may not have himself explored the consequences of integrating less developed countries into an international financial system, his analytical framework is a useful way of addressing this question. In particular the paper shall argue that the asymmetric integration of less developed countries into the international financial system provided a buffer for advanced capitalist countries at the center, allowing countries in the core to evade to a greater extent the inherent tendency to debt deflation by exporting fragility to the periphery. Marx's analysis of the role and functions of money already contained the notion of money as an embodiment of power internationally. His unitary conception of credit and financial systems is a useful way to address the questions of imperialism and uneven development.

Marx had distinguished "national spheres of circulation" where the state would establish the standard of price from the international arena where bullion functioned as world money: the means of settlement of international payments. For Marx the hoarding of gold by nations implies that the monetary power of the state is constrained by that of other states (De Brunhoff 1986) and, unlike other classical political economists, Marx did not entirely dismiss the mercantilist preoccupation with hoarding gold (Marx 1970[1859]: 158-159). Thus, world money in the form of bullion serves as "the universal means of payment, as the universal means of purchase, and as the absolute social materialization of wealth as such" (Marx 1976 [1867]: 242). Payments have to be settled with a transfer of "world money" and it also serves as the means by which wealth is redistributed across nations. It is in this sense that it also becomes a measure of power between nations (Marx 1973: 227). Such a conception, of the acquisition of money in the form of reserves or hoards as "social power in a material form," is contingent on the international social 
relations: the international division of labor and the international financial system that mediates this division.

The hierarchical structure of Marx's theory of money was based on an international commodity money system in the specific context in which he was writing. The actual evolution of the international monetary system towards the end of the nineteenth century witnessed the use of credit money - the monetary liabilities of a state - as world money. Instead of bullion, fictitious capital is now the form in which balance of payments' settlements are made. Thus the valuation and management of state debt is an appropriate starting point for comprehending contemporary monetary systems (Foley 2005).

Marx's formulation suggests a link between the mechanisms of accumulation of "world money" and imperialism, which this paper seeks to develop. The extension of Marx's approach, to explore this link, leads from the discussion of money as a means of payment taking the form of a financial asset (fictitious capital), through its role as world money, to a comprehension of the development of imperialism within Marx's theory of money. The commercial relations mediating the international division of labor are in the process also transformed into a financial system. ${ }^{10}$

The rest of the paper explores the process by which a credit money standard takes on the functions of world money and how historically the development of the international financial system resolved the contradictions of the money-form with the establishment of the dominance of the currency of a single country in the settlement of international payments. The dominance of finance and the integration of countries in the periphery into the global financial system have been the concrete mechanisms by which the leading country has asserted and preserved its position at the center of the global capitalist system. Britain's role in the gold standard era, and the role of the United States in the post-Bretton Woods period, were both fostered by growing financialization and financial integration. ${ }^{11}$

\section{The Historical Evolution of the International Financial System}

\section{I The Gold Standard}

By the last decades of the nineteenth century the actual workings of the international monetary system had moved significantly beyond its metallic basis. Relatively small actual transfers of gold were able to support the massive growth of trade and capital flows through this period (Bloomfield 1959, 1963; Eichengreen 1996; Lindert 1969). The international gold standard was in effect a "pound sterling" standard.

Keynes in his analyses of the relatively smooth functioning of this system pointed to the manner in which England exercised its dominance over the internal financial system, and the pivotal role that London played as the largest capital market and trade center in replenishing the gold supplies of its partners. The Bank of England managed to calibrate international movements of gold, acting as the "conductor of the international orchestra," while keeping relatively small gold reserves through movements of its discount rate. The

10. So while trade must ultimately balance out between nations this is not true of the balance of "claims" that may or may not balance (Marx 1981: 649). See also De Brunhoff (1976).

11. Vasudevan (2008) presents a detailed comparative-historical analysis of the two periods. 
ability of the Bank of England to deploy the discount rate to induce a net inflow of capital hinged on the privileged international position of England in the international financial markets. Concentration of the pattern of international settlement through the London markets, and the various measures deployed to economize on the use of bullion, promoted the increasing recourse to sterling monetary liabilities, and the Bill on London, instead of actual bullion (Lindert 1969).

Marx had undertaken an analysis of the how bills of exchange circulate as means of payment and form the basis of credit money proper (Marx 1981[1895]). These bills are essentially securities and Marx investigated the impact of the interest rate in determining the price of these instruments which were a form of fictitious capital. With the acceptance of the bill as a medium of international transactions and for the financing of international trade, the role of the bill market in financial intermediation was extended internationally. ${ }^{12}$ However, the movement of international capital was increasingly outside the regulatory control of the Bank of England and the constraints of the Banking Act of 1844 which set limits to the bank's interventions in the money market on the basis of reserve holdings (Pressnell 1968). Liquidity in the monetary system was sustained by parallel unregulated private flows. The Bill on London was transformed from an actual mercantile transaction to a purely financial instrument traded in the quest for arbitrage opportunities.

The "imperial system," the institutional structure of the credit relations underpinning Britain's relation to its empire and to primary export producers in the periphery, played a critical role in this process. The interconnecting network of multilateral trade, revolving around England, whereby England financed its deficits with the United States and continental Europe through the surpluses of the empire, in particular India, became crucial to the stability of the system (Saul 1960). Sterling came to take on the mantle of world money, with the use of gold in the settlement of international payments becoming increasingly less important. But far from being self-regulated, the gold standard was supported and preserved by British imperial policy (De Cecco 1986; Vasudevan 2008).

The practice of augmenting reserves with convertible foreign exchange became prevalent in the pre-war world. Countries of the empire, including India, Malaysia, Ceylon, Siam, and the Straits' settlements all came to adopt some form of the gold exchange standard. Sterling reserves, which were perceived to have zero risk, acted like a line of defense that protected the gold reserves of countries that had vulnerable payments' positions and sought to defend their parities (Bloomfield 1969; Lindert 1969). This imparted a greater elasticity to the sterling system as a whole and facilitated credit expansion, as long as the financial center in London did not regard the increase in liquid claims owed to foreign long-term borrowers as a reason for contracting its own credit superstructure (Williams 1968; Kindleberger 1985, 1996).

From the framework of Marx's monetary analysis, the international monetary system evolved to one where world money took on the form of fictitious capital, credit money of a country rather than gold emerges historically as an outcome of the contradictions of the

12. Nishimura's study shows that after a period of decline in the volume of bills through the seventies and eighties there was resurgence in the growth from the nineties. However, this growth was predominantly that of foreign bills. Inland bills reached a peak around 1873 (comprising about 83 percent of national income in between 1861-71) and declined thereafter. Foreign bills, which had increased till 1873 also declined during the $1870-80$ s, but the recovery of foreign bills in the 1890 s outpaced that of inland bills. The peak of this recovery was in the first decade of the 20th century (Nishimura 1971: 25, Table 15). 
money form. The monetary constraints imposed by the need for bullion in settling international payments are transcended by the greater elasticity imparted by the use of credit money. The chain of credit obligations that fuelled the growth of international trade and liquidity also afforded the capitalist core of the global markets relative immunity from the destabilizing contagion effects of the debt-deflationary crises that Marx noted in his discussion of the volley firing of bullion crisis.

Throughout the gold standard period the international monetary system as a whole was in general able to weather the crises which did erupt relatively painlessly, and without impairing the overall mechanism or threatening convertibility at the center. This smooth functioning has been attributed to Britain's role as a lender of last resort, but London's ability to act as "a lender of last resort" was based on other countries' willingness to hold pound liabilities. While borrowing from the market was one method, the Bank of England, when faced with the threat of a gold drain, was also able to borrow from "special depositors," including the governments of India and Japan. The empire provided a critical source of surplus that was recycled through London when countries like France proved less willing to provide the necessary cushion (de Cecco 1983).

But the countries on the periphery did not display a similar pattern of smooth adjustment and experienced perverse capital movements, convertibility crises, devaluations, and terms of trade fluctuations. ${ }^{13} \mathrm{~A}$ sudden rise in interest rates in London could attract shortterm funds from countries that had been in a balanced position, precipitating a drain of reserves. Such liquidity crises occurred for example in Argentina during the 1890 Barings crises, Brazil in the 1890s, and again when the Australian land company bubble burst in 1893. These crises were aggravated by the sudden withdrawal of British deposits (Bloomfield 1969; Fishlow 1985).

The asymmetry in the adjustment mechanism between the leading financial center, Britain, and the debtors in the periphery arises from their differential pulling power (Gallarotti 1999; Lindert 1967). A tightening in the financial center in London during a crisis could be transmitted to other leading centers, sparking a deflationary spiral. However, the ability to draw an inflow from the peripheral countries would impart a greater resilience to the adjustment mechanism (Lindert 1967: 47-50). While on one hand Britain recycled liquidity to the periphery through capital outflows, it could, by sharply curtailing investments and lending, redistribute the real burden of adjustment to the periphery during times of crises (Ford 1962; Lindert 1967).

The integration of the nations within the gold standard system did not abolish the division of the world into spheres of nation states or eliminate rivalries (De Brunhoff 2006). The system came under increasing strain with growing competition from Germany, France, and the United States. In fact the instability of the interwar period, and the ill fated attempt to restore the gold standard, reflect the contradictions of the system based on the ability of London to preserve the dominance of the pound in the face of growing deficits of the UK, and the unraveling of imperial hegemony. The problem stemmed not so much from the return to a gold exchange standard, but the undermining of the international financial mechanisms based on sterling liabilities following the erosion of Britain's imperial hegemony. The crisis did manifest itself, however, in an increased demand to convert

13. Triffin (1964); Ford (1956, 1960); Fishlow (1985). The different experience of the core and periphery has been explained in terms of absence of a credible commitment mechanism in these countries (Bordo and Shwartz 1999). 
sterling reserves into gold in the context of the volatile exchange rate fluctuations of this period. It is in this sense that the sterling financial edifice displayed a tendency to collapse back to a metallic basis, until England suspended convertibility in 1931.

\subsection{The Emergence of the Floating Dollar Standard}

The postwar Bretton Woods system saw the establishment of a dollar-gold standard. The United States emerged from the Second World War with substantial reserves of gold and as the leading creditor in the international arena. Initially, the mechanism of offsetting capital flows under the postwar reconstruction plans of Europe and Japan, and economic and military aid by the United States, underpinned the role of the dollar (while relieving the problem of the dollar shortage) in the settlements of international balances.

Throughout this period of postwar transition, the newly created IMF institution played only a marginal role (Block 1977; Parboni 1985). Its role as an alternative channel of generating international liquidity was limited. There was a shift in attitude towards the role of the IMF with the relaxation of the terms of lending that prohibited IMF lending to finance "large and sustained capital outflows" under the Articles of Agreement during the Suez crisis in 1956. A new reserve asset, the Special Drawing Rights (SDRs), was created in 1969, though stricter repayment provisions muted the expansionary potential of the device. While providing some additional liquidity to alleviate the pressure on the dollar, the SDR arrangements did not impinge on the dollar's international role (Eichengreen 1996; Block 1977; Helleiner 1994; Parboni 1985).

However, as Europe and Japan emerged as competitors to U.S. industry, the U.S. current account balances began deteriorating through the sixties. The accumulation of shortterm dollar liabilities exceeded its gold stocks, and the possibility of a speculative run on the U.S. gold stock posed a threat to the international payments mechanism. The demands of financing the Vietnam War compounded the problem. The inadequacy of the prevailing financial arrangements for providing offsetting finance and the system of unilateral capital controls to contain speculative flight was evident as capital fled from the United States to Western Europe, fuelling inflation in these countries. France and Germany initiated moves to convert dollars holdings into gold, until finally in August 1971 the U.S. government, which had been resisting pressures for domestic adjustment, suspended gold convertibility (Helleiner 1994; Eichengreen 1996; Parboni 1985).

The abandonment of gold convertibility by Britain in 1931 led to a collapse back to gold in international settlements, and set in motion a period of "rolling deflation," competitive devaluations, and ultimately the erosion of the role of sterling in international exchange. In contrast, the closing of the gold window in 1971, and the subsequent "floating" of the dollar, did not result in the displacement of the dollar as the international reserve currency (Parboni 1985). Instead, developments in the international monetary arrangements in the past three decades enabled the preservation of the role of the dollar as an international reserve (Shulmeister 2000; Serrano 2002; Mckinnon 2001; D'Arista 2002, 2004). However, the international monetary system, based on the holdings of dollar liabilities, had moved beyond its basis in gold.

At the heart of this process was the emergence of parallel, unregulated monetary mechanisms that had burgeoned through this period. Sections of the U.S. regime had been promoting the expansion of private dollar investment, as an alternative to official channels, as a 
solution to the problem of international liquidity (Helleiner 1994). The control over sources of international liquidity also enhanced the desirability of dollar denominated capital flows. In particular, the eurodollar market had emerged in the sixties as an outcome of U.S. attempts to restrict capital outflows. U.S. transnationals increasingly began to finance overseas operations through this growing market which was moreover entirely unregulated. This burgeoning offshore market, which was both liquid and unregulated, proved an important means for encouraging foreign investors to finance the U.S. deficit. With the dollar denominated surpluses of the OPEC countries being recycled through this market in the seventies, the market grew to be a full fledged capital market. ${ }^{14}$ Private investors in offshore markets thus came to play a critical role in financing the U.S. deficit.

The massive growth of this offshore market signaled the decisive shift away from the restrictive Bretton Woods system. It paved the way for the concerted advocacy of financial openness and integration in the interests of preserving dollar dominance. The U.S. agenda for a post-Bretton Woods refashioning of the international monetary system as a "pure" dollar standard was rooted in the aggressive pursuit of liberalized financial markets (Helleiner 1994). Such integration imparted a greater elasticity to the adjustment mechanisms in the core and the proliferation of financial instruments; the surge of financial flows - financialization - played an important role in preserving and extending the role of the dollar as world money.

These private capital flows are in essence analogous to the market for sterling bills that proliferated independently of the Bank of England's regulatory ambit. Capital markets were fostered as the key mechanism for recycling surpluses to developing countries, in particular through syndicated dollar denominated loans to sovereign borrowers in Latin America through the seventies. The trend towards deregulation in the United States was matched by moves to liberate economies in Latin America from the yoke of "financial repression." Disinflation, deregulation. and the freeing of the interest rates in these countries fuelled the inflow of private foreign capital, a precursor to financial fragility (DiazAlejandro 1985). In the face of growing inflationary pressures after the 1978-79 dollar crisis, the United States chose to adopt austerity measures, the Volcker program, in order to stabilize the dollar. The steep hike in interest rates precipitated payments problems for the Latin American debtor countries. This "coup of 1979" signaled the onset of the era of neoliberalism and also had significant international repercussions precipitating the debt crisis of the eighties as developing countries found themselves unable to bear the burden of debt repayment (Dumenil and Levy 2004).

The debt crisis of the eighties became the means by which a further impetus was given to private international flows of capital, for instance through the instrumentality of debt equity swaps. These swaps transformed debt into tradable bonds through the creation of Brady bonds (named after U.S. Treasury Secretary Nicholas Brady, who initiated this market-oriented bail out plan in 1989). A Brady bond is essentially a structured derivative product, and investment banks began to extend the Brady principle to other types of developing country debt, creating a variety of structured loans (Kregel 1998). The early nineties witnessed a fresh influx of private capital flows to "emerging markets," ending abruptly

14. Spiro (1999) discusses the pressure that the U.S. state brought to ensure that OPEC surpluses were recycled through private channels of the eurodollar markets. Proposals to channel these surpluses through official IMF channels were effectively blocked, as were the proposals to impose controls on the eurodollar market. 
with the Asian crisis of 1997-8. The tremendous surge of capital flows exposed these countries to the volatility and fragility of financial bubbles. The collapse of asset prices and the currency crisis were precipitated as investors fled from these markets.

In fact, contagion effects of financial crises in emerging markets of Latin America in 1994 and Asia in 1998 bear strong resemblance to the "volley firing" effect that Marx discussed in the context of the "commercially developed" countries. Instead of a drain of bullion, the forced export of goods, and the bankruptcy of importers, the financial crises manifest themselves in speculative capital flight, a collapse of the banking system, and a run on the domestic currency. These become the principal transmission mechanisms of the contagion effect. The second difference is that in the period Marx was writing about, the contagion spread within the developed capitalist world, while in the present conjuncture the impact of the contagion has been more pronounced outside this core. But these developments do not negate the central analytical argument of Marx's monetary theory.

The crises are a reflection of the monetary constraint on the world capitalist economy. However, the displacement of debt deflationary crisis to the periphery allowed an easing of the external constraint for the center. Financial crises in the emerging markets through the nineties served as a safety valve, a line of defense against speculative attacks on the dollar while capital flight in the aftermath of crisis also helped preserve the role of the dollar. At the same time the responses to the crisis - the bail out packages - were geared to reinforcing the dominance of finance. The analyses of the pattern of episodes of financial crisis (Eichengreen and Bordo 2002) in both the gold standard period, and after the collapse of Bretton Woods, reveal that the incidence is disproportionately larger in the periphery compared to the core. In the inter-war years when the emerging markets in the periphery did not play the role of a buffer, in contrast, a proportionately larger number of crises occurred in the core countries (Eichengreen and Bordo 2002: Table 6).

Ever since the U.S. government brokered the Plaza accord in 1985, which committed G5 countries to adjust their monetary and fiscal policies in order to effect an orderly depreciation of the dollar, foreign central banks have also become implicated in defense of the dollar. Official purchases of dollars received the first big boost since the collapse of the Bretton Woods arrangements (Eichengreen 1996: 149-152). With the waning of OPEC surpluses in this period, these "official holdings" of U.S. treasury bills, like the sterling balances of pre-World War I Japan, played a pivotal role in the multilateral clearing mechanisms of the "floating-dollar regime."

This dependence on official dollar holdings has been christened a "Revived Bretton Woods System" (Dooley et al. 2003, 2004), as China in particular maintains huge dollar reserves. But the international monetary regime that has been forged in the last two decades is not so much a Revived Bretton Woods System as it is a reconstruction of the parallel monetary mechanisms of the British imperial system outlined earlier. Liquidity in the post-Bretton Woods dollar standard derives from multilateral clearing mechanisms and financial intermediation similar to the sterling bill-financed triangular patterns of settlement of the British Empire. Official intervention by foreign central banks plays a role analogous to that of sterling deposits of India and Japan in the earlier period. At the same time, in both periods the burden of adjustment falls disproportionately on the countries in the periphery, which were faced by financial crisis precisely because of their integration into the international financial system. 


\subsection{The Credit Money Standard, Financialization, and Financial Integration}

What seems to emerge from the initial historical survey of the pound and the dollar standard is that the use of a national currency as a reserve currency, while significantly facilitating the expansion of the world market, also contains within it an inherent contradiction. The increasing use of "credit money" or fictitious capital instead of gold in the settlement of international payments, along with the development of the financial and credit system internationally, in particular from the end of the nineteenth century, were integral to the tremendous growth experienced in this period. The currency of a country emerged as the "world money." This was both a logical outcome and a necessary basis of the development of capitalism and the tremendous concentration of capital and trade flows in the dominant country. The system was able to support the growth of international trade and capital flows significantly beyond the constraints of the gold reserves.

A country's dominance in world trade and its status as the leading creditor and exporter of capital initially underwrites the emergence of its currency as the international reserve currency: world money. We have seen that the currency of the country with the largest surplus and the most extensive trade relations emerges as the international reserve currency. It would be demanded and accepted in the final settlement of balance of payments, and would be world money in the sense of being a representation of material wealth.

The smooth functioning of the international monetary system is, however, reflected in the adequacy of the international reserves in the hands of deficit countries. Its trading partners have to be able to accumulate reserves of this currency. As a means of purchase, world money is acquired through unilateral transactions. International liquidity and the maintenance of sufficient global reserves depend on the ability of the country issuing the international money to sustain a deficit without eroding its status as world money. It has to withstand the possibility of speculative attacks by offsetting capital flows. The adjustment mechanism for the deficit of such a country (and its impact) is qualitatively different from the deficit of less developed countries. Instead of being compelled to depreciate its currency and to follow deflationary policies, it can shift the burden of adjustment on to its trading partners. It is in this context that specific institutional mechanisms that relate both to the evolution and proliferation of finance and the exercise of imperial power play a pivotal role in allowing the core to evade the consequences of debt deflationary crises. The parallel monetary mechanisms of the sterling bill market in particular enabled the expansion of international liquidity far beyond the metallic base of gold reserves during the international gold standard period. The brunt of financial fragility is borne to a disproportionate extent by countries in the periphery.

However, the crises of the inter-war years signaled the "involution" of the monetary system back to a gold basis, and more important the resort to bilateralism and protectionism undermined the multilateral system of settlements centering on the City of London. The debilitating devaluations and trade wars of this period reflect the assertion of the deflationary logic of the international monetary system that both Keynes and Marx had analyzed.

The United States was faced with such a crisis in the wake of the deficits and payments problems created by the Vietnam War. The closing of the gold window in 1971, however, did not result in a collapse back to gold or the displacement of the dollar as "international money." Instead, with the subsequent "floating" of the dollar, the generation of international liquidity was in effect severed from its basis in gold. The long transition to the 
"floating dollar standard" was in a sense complete. The eurodollar markets recycled surpluses to emerging markets through the seventies and early eighties. In the nineties, private equity groups and hedge funds emerged as big financial investors and intermediaries alongside traditional financial institutions. Financial innovations - the proliferation of instruments that securitized risk - have fuelled this tremendous growth of financialization in the past decade.

The historical overview highlights that private capital flows and financialization have been integral to the establishment and preservation of both the sterling and the floating dollar standard. A crucial difference between the two periods is the extent of disengagement of the international financial system from "gold money," with the fruition of the evolving "credit money" standard and the tremendous growth of financialization globally. The international monetary system has moved significantly beyond its basis in bullion.

This complex system of international financial relations remains in a fundamental sense a "monetary" system, but the contradictions latent in the money form have by no means been transcended. As Marx had argued:

It is an inherent property of money to fulfill its purposes by negating them, to be a means which becomes an end, to realize exchange value of commodities by separating them from it; to facilitate exchange by splitting it; to overcome the difficulties of the direct exchange of commodities by generalizing them; to make exchange independent of the producers in the same measure as the producers become dependent on exchange. (Marx 1973: 236)

The credit crisis unfolding in the leading financial centers since the summer of 2007 is evidence that these contradictions continue to assert themselves.

\section{Conclusion}

The dominance of finance and the integration of countries in the periphery into the global financial system have historically been the mechanisms by which the leading country has asserted and preserved its position at the center of the global capitalist system. Britain's role in the gold standard era and the role of the United States in the post-Bretton Woods period were both fostered by growing financialization. At the same time the asymmetric manner in which countries in the periphery were integrated into this system in both periods enabled a displacement of the debt deflationary spiral that advanced capitalist countries subjected to the periphery. This aspect of imperialism and uneven development has been shown to emerge from the logical structure of Marx's analysis, in particular his discussion of fictitious capital and of the role of money as world money.

The argument of the paper suggests that there is a link between the growing global imbalances, financialization, and the mechanisms. A consequence of the tremendous international liquidity that the floating dollar standard has provided manifests itself in the structure of global imbalances and the consequences for financial fragility. Financialization and the export of fragility to the emerging markets of the periphery have been pivotal to preserving and extending the dollar standard. The role of global imbalances and the U.S. deficit historically mirrors that of the "thin film of gold" in the hands of the Bank of England during the heyday of the international gold standard. Even though Britain experienced trade deficits through this period, it still enjoyed current account surpluses on the 
basis of interest and income earnings from foreign investments (which exceeded its trade deficits through this period). Britain exercised an exorbitant privilege in its role as the issuer of the international reserve currency.

One explanation of the puzzle of the persistence of global imbalances points to the fact that the United States has been reaping higher returns on its assets, giving rise to persistently positive net income receipts: a "net return premium" in the post-Bretton Woods period (Gourinchas and Rey 2002). The United States, like Britain, exercises an exorbitant privilege in its role as the "world banker" (Gourinchas and Rey 2005). Arguing that there is "something misleading about calling a country that makes money on its financial position the world's largest debtor," Hausmann and Sturzenegger (2005) put forward the controversial thesis that the United States is in fact a net creditor if one takes into account the capitalized values of the net income earnings from foreign assets. The net income receipts represent the export of what has been christened "dark matter" (Hausmann and Sturzenegger 2005).$^{15}$ The dark matter thesis suggests that the United States could in theory continue to accumulate liabilities to finance its current account deficits through the export of "dark matter." The "return premium" is implicitly conceived as an inherent property of the U.S. asset base, and its existence is seen to signify a real basis for the United States's ability to borrow globally. Thus, despite a loss of competitiveness in production, as manifested in its growing trade deficits, the return premium accrues to U.S. capital because of its inherent "knowledge advantage, as insurance premium or its liquidity generating ability" (Hausmann and Sturzenneger 2005). What gets obscured in this formulation that fetishizes valuation effects into an independent source of wealth creation is the fact that the United States is drawing surpluses from an international division of labor, specifically from the expropriation of surpluses in the rest of the world. This inversion of the real logic of capitalist relations is precisely what Marx critiqued in his analysis of valuation of public debt in terms of fictitious capital (Marx 1978: Part V). In the dark matter thesis we see the same inverted logic being applied to the privileged international position of the United States in global financial markets. ${ }^{16}$

The plunge of the value of the dollar in the wake of the sub-prime crisis lays bare the tenuous basis of the financial pyramid sustaining the global imbalances and international liquidity and reveals the limits and constraints on the imposition of the dollar standard. But the exact form of the unraveling of this system is far from certain. What is indisputable is that we are witnessing the reassertion of the monetary constraint in the context of the floating dollar standard. Sections of the financial press have been characterizing the present

15. In 2004, for instance, the United States earned more on its assets than its liabilities to the tune of $\$ 30$ billion on a net liability base of $\$ 2.3$ trillion. This corresponds, on a 5 percent rate of return in perpetuity calculation, to a present value of $\$ 600$ billion.

16. In fact the idea in some ways is not new. In 1772 Dr. Price writes, "A state need never therefore be under any difficulties; for with the smallest savings it may in as little time as its interest rate can require pay off the largest debts." Quoted by Marx (1978: 520) as a "charming theoretical introduction to English national debt." Marx goes on to critique the conception:

“... Interest- bearing capital, however, displays the conception of capital fetish in its consummate form, the idea that ascribes to the accumulated product of labor, in the fixed form of money at that, the power of producing surplus-value in geometric progression by way of an inherent secret quality, ... so that this accumulated product of labor ... has long since discounted the whole world's wealth ...." (Marx 1981: 523) 
conjuncture as a "Minsky moment": the point after a long boom in asset prices when asset prices collapse thereby precipitating a bust in the cycle. But it is equally a reflection of the contradictions of the money-form that Marx analyzed.

The freeze of the credit markets following the rapidly escalating financial crisis in the first two weeks of September brought down financial institutions in both the United States and Europe. The relative immunity of the center has been undermined with the current credit crisis. It is possible that the global monetary system will move to a more multi-polar currency standard, with the euro establishing itself as a strong competitor. This might lead to more pronounced contagion effects in the core countries as in the inter-war period or the seventies.

On the other hand, with the crash in emerging market currencies in Korea, Hungary, and Ukraine, an unraveling in the periphery remains a possibility. Even as the sub-prime market crisis rocked financial markets, the flows to developing countries surged in 2007 by about 40 percent from its 2006 level as capital flowed out of the United States. Current account surpluses and large reserves have accrued in many emerging market countries, while the central banks and sovereign wealth funds emerged as prominent players and sources of funds in the international capital markets in the initial stages of the crisis. But as governments and central banks in the United States and Europe struggled to shore up markets and rescue the collapsing financial system after the credit freeze in September 2008 , investors globally began to seek the safety of the dollar. This ushered in a new phase of the crisis as the implosion of the international financial system propelled an unwinding of currencies and capital flight from many emerging markets, especially in Eastern Europe in October 2008. The retreat from emerging markets revived the fortunes of the dollar which began to appreciate against most currencies (apart from the yen). The dollar's role as international money is being asserted even as a debt-deflationary shock paralyzes the global economy. As the international financial system continues to evolve and fashion ways of tapping and recycling surpluses and export fragility to the periphery, the outcome for the dollar standard is not a forgone conclusion.

\section{References}

Arnon, A. 1984. Marx's theory of money: The formative years. History of Political Economy 16: 555-575.

Block, F. L. 1977. The origins of international economic disorder: A study of United States international monetary policy from World War II to the present. Berkeley: University of California Press.

Bloomfield, A. 1959. Monetary policy under the international gold standard. New York: Federal Reserve Bank of New York.

Bloomfield, A. 1963. Short term capital movements under the pre-1914 gold standard. Princeton, NJ: International Finance Section, Dept. of Economics, Princeton University.

d'Arista, J. 2002. Financial regulation in a liberalized global environment. In International capital markets: Systems in transition, ed. J. Eatwell and L. Taylor. New York: Oxford University Press.

d'Arista, J. 2004. Dollars, debt and dependence: The case for international monetary reform. Journal of Post Keynesian Economics 26 (4): 557-572.

De Cecco, M. 1984. The international gold standard: Money and empire. New York: St Martins Press.

De Brunhoff, S. 1976. Marx on money. New York: Urizen Books.

De Brunhoff, S. 1998. Money, interest and finance in Marx's Capital. In Marxian economics: A reappraisal: Essays on volume III of Capital, vol. 1, ed. R. Bellofiore, 176-189. London: Macmillan. 
De Brunhoff, S. 2005. Marx's contribution to the search for a theory of money. In Marx's theory of money: Modern appraisals, ed. F. Moseley. New York: Palgrave Macmillan.

Dooley, M., D. Folkerts-Landau, and P. Graber. 2004. The revived Bretton Woods system. International Journal of Finance and Economics 94 (4): 307-313.

Dumenil G., and D. Levy. 2004. Capital resurgent. Cambridge: Harvard University Press.

Eichengreen, B. 1996. Globalizing capital: A history of the international monetary system. Princeton: Princeton University Press.

Eichengreen, B., and M. Bordo. 2002. Crises now and then: What lessons from the last era of financial globalization. NBER Working Paper 8716.

Epstein, G. 2006. Introduction. In Financialization and the world economy, ed. G. Epstein. Edward Elgar.

Foley, D. 1983. On Marx's theory of money. Social Concept 1 (1): 5-19.

Foley, D. 1986. Understanding capital. Cambridge: Harvard University Press.

Foley, D. 2005. Marx's theory of money in historical perspective. In Marx's theory of money: Modern appraisals, ed. F. Moseley. New York: Palgrave Macmillan.

Gallarotti, G. M. 1995. The anatomy of an international monetary regime. London: Oxford University Press.

Gourinchas, P., and H. Rey. 2005. From world banker to world venture capitalist: US external adjustment and the exorbitant privilege, NBER Working Paper 11563. Cambridge, MA: National Bureau of Economic Research.

Hausman, R., and F. Sturzenegger. 2006. Global imbalances or bad accounting? The missing dark matter and the wealth of nations. Center for International Development Working Paper 124. Cambridge: Harvard University.

Hawley, J. 1987. Dollars and borders: US government attempts to restrict capital flows, 1960-1980. Armonk, NY: M. E. Sharpe.

Helleiner, E . 1994. States and the reemergence of global finance: From Bretton Woods to the 1990s. Ithaca, NY: Cornell University Press.

Keynes, J. M. 1980. Collected writings of John Maynard Keynes volume XXV: Shaping the post war world: The clearing union. London: Macmillan.

Kindleberger, C. 1985. International financial markets and capital movements. Essays in International Finance 157. Princeton: Princeton University.

Kindleberger, C. 1996. Manias, panics and crashes. New York: John Wiley and Sons.

Gretta Kregel, J. 1998. Derivatives and global capital flows: Applications to Asia. Cambridge Journal of Economics 22: 677-6.

Krippner, G. 2005. The financialization of the US economy. Socio-Economic Review 3 (2).

Lapavitsas, C. 1994. The banking school and the monetary thought of Karl Marx. Cambridge Journal of Economics 18 (5): 447-461.

Lapavitsas, C. 1996. The classical adjustment mechanism of international balances: Marx's critique. Contributions to Political Economy 15: 63-79.

Lindert, P. H. 1969. Key currencies and gold, 1900-13. Princeton Studies in International Finance 24, International Finance Section, Princeton University.

Marx, K. 1972[1859]. A contribution to a critique of political economy. Chicago: International Library Publishing.

Marx, K. 1973. Grundrisse. London: Penguin.

Marx, K. 1976 [1867]. Capital: Volume I. London: Penguin.

Marx, K. 1981[1895]. Capital: Volume III. London: Penguin.

Mckinnon, R. 2001. The dollar and the sustainability of the US current account deficit.. Brookings Institutions Paper 1: 227-239.

Minsky, H. 1975. John Maynard Keynes. New York: Columbia Press.

Nishimura, S. 1971. The decline of inland bills of exchange in the London money market, 1855-1913. London: Cambridge University Press.

Parboni, R. 1985. The dollar and its rivals. New York: Verso. 
Pressnel, L. S. 1968. Gold reserves, banking reserves and the banking crises of 1890. In Essays in money and banking in honor of R. S. Sayers, ed. C. R. Whittlesey and J. S. G. Wilson. Oxford: Clarendon Press.

Rosdolsky, R. 1977. The making of Marx's Capital. London: Pluto Press.

Saul, S. B. 1960. Studies in British overseas trade: 1870-1914. Liverpool: Liverpool University Press.

Sayers, R. S. 1985. The working of the gold standard. In The gold standard in theory and history, ed B. Eichengreen. New York: Methuen.

Serrano, F. 2003. From the static gold to the floating dollar. Contributions to Political Economy (22): 87-102.

Shulmeister, S. 2000. Globalization without global money: The double role of the dollar as national currency and world currency. Journal of Post Keynesian Economics 22 (3): 365-395.

Spiro, D. E. 1999. The hidden hand of American hegemony. Ithaca, NY: Cornell University Press.

Triffin, R. 1964. The evolution of the international monetary system: Historical reappraisal and future perspectives. Princeton Studies in International Finance 12.

Vasudevan, R. 2008. The borrower of last resort: International liquidity and adjustment in historical perspective. Journal of Economic Issues (forthcoming).

Williams, D. 1968. The evolution of the sterling system. In Essays in money and banking in honour of R. S. Sayers, ed. C. R. Whittlesey and J. S. G. Wilson. Oxford: Clarendon Press.

Ramaa Vasudevan is an assistant professor in the department of economics at Colorado State University. Her research is focused on the implications of trade and financial flows for uneven development. 